\title{
The Optimization Of Collimator Design And In-Vivo Testing Of Boron Neutron Capture Therapy On Radial Piercing Beamport Kartini Nuclear Reactor By Monte Carlo N-Particle Extended Simulation Method
}

Ikna Urwatul Wusko ${ }^{1 *}$

${ }^{1}$ Sari Mulia School of Health Science, Pramuka No.2 Rt.07, Banjarmasin

*ikna@stikessarimulia.ac.id

Kusminarto ${ }^{2}$

${ }^{2}$ Fisika FMIPA-UGM, Sekip Utara Bulaksumur, Yogyakarta 55281, Indonesia kusmin@ugm.ac.id

Yohannes Sardjono $^{3}$

${ }^{3}$ PSTA-BATAN, Jln. Babarsari Kotak Pos 6010 ykbb, Yogyakarta 55281 , Indonesia.

Sardjono.batan@gmail.com

Effan Najwaini ${ }^{4}$

${ }^{4}$ Banjarmasin State Polytechnic, Jl. Brigjen H. Hasan Basry, Banjarmasin 70123

effan.najwaini@gmail.com

\begin{abstract}
Objective: This study aims to obtain an alternative method to reduce the tumor. Optimization of collimator and in vivo Boron Neutron Capture Therapy (BNCT) materials on translucent beam reactor Kartini Reactor eligible IAEA.

Method: BNCT is a kind of alternative nuclear therapy that utilizes the reaction of ${ }^{10} \mathrm{~B}(\mathrm{n}, \alpha){ }^{7} \mathrm{Li}$ which produces a total kinetic energy of $2.79 \mathrm{MeV}$. Linear Energy Transfer (LET) from $\alpha$ and ${ }^{7} \mathrm{Li}$ particle recoil will be stored locally at a distance of 5-9 $\mu \mathrm{m}$. Optimization of collimator design is by varying the walls of collimators, moderators, filters and gamma shields. Such optimizations produce epitermal neutron flux values, current components, thermal neutron components, rapid neutron dose components and gamma dose components according to IAEA requirements by utilizing Monte Carlo N-Particle Extended (MCNPX) simulations.

Results: This study produced the best collimator design of $1.75 \mathrm{~cm}$ thick Ni-nat as a collimator wall, $\mathrm{Al}_{2} \mathrm{~S}_{3}$ as thick as $29 \mathrm{~cm}$ as moderator, $\mathrm{Al}_{2} \mathrm{O}_{3} 0.5 \mathrm{~cm}$ thick as filter, $\mathrm{Pb}$ and $\mathrm{Bi}$ as thick as $4 \mathrm{~cm}$ as a shield of collimator and Bi gamma end as thick as $1.5 \mathrm{~cm}$ as a gamma shield.

Conclusion: This study concludes that the optimization of collimator designs meets the needs of the IAEA and can be simulated for in vivo test radiation.
\end{abstract}

Keywords: Boron Neutron Capture Therapy, In vivo testing, Kartini Reactor, Optimation.

\section{INTRODUCTION}

Various diseases threatening human health worldwide. According to data from the WHO (World Health Organisation) in 2014, total data of human deaths worldwide 56 million during 2012, of the 36 million is what is the number of deaths from noncommunicable diseases, or noncommunicable diseases (NCDs). There are four predominant types of NCDs, namely cardiovascular diseases, chronic respiratory diseases, diabetes and cancer. The number of deaths of cancer 
cases in the world 8.2 million people, this value is $21.7 \%$ of the total cases of NCDs mortality data that makes cancer a deadly disease number two after heart disease [1].

Cancer is a group of diseases characterized by the growth of cells in the body that are abnormal and uncontrolled spread. Uncontrolled spread of these can lead to death so needed therapy to inhibit and eliminate cancer cells [2]. Some cancer treatment therapies include surgery, chemotherapy and radiotherapy. All three have weaknesses just for conditions such tumors at an early stage, using drugs which have side effects and also using high-dose radiation. To overcome some of these weaknesses have been developed Boron Neutron Capture Therapy (BNCT) which is selective against cancer cells [3].

A technical review of 300 therapies that have been performed at the Finnish BNCT facility in various clinical trials. In this technical study, we discussed research in the field of medical physics to form the basis for BNCT patient care in Finland as well as the possibility to further develop the method used and optimize it in the future. With a range of aspects including neutron sources, file dosimetry, treatment planning, boron imaging progression and ultimately it is possible to detect effectiveness in patients from BNCT [4].

Kartini reactor neutron source research facility has been used for BNCT. Beam translucent port used for in vivo tests because of beam port closest to the reactor core so that it has a high neutron flux at the base.

\section{RESEARCH METHODS}

This research used MCNPX simulation which used study of cooperation literature with PSTA BATAN Yogyakarta.

\section{Collimator system optimization}

Collimator system optimization in this study consists of three parts, namely a moderator, filter and shield gamma. Moderator serves to decrease the energy of fast neutrons for the epithermal neutron energy, so that the parameters used are $\dot{\mathrm{D}}_{\mathrm{f}} / \Phi_{\text {epi }}$ namely fast neutron dose rate per epithermal neutron flux [5].

With good criterion moderator material is a material that has a value $\dot{\mathrm{D}}_{\mathrm{f}} / \Phi_{\mathrm{epi}}<$ $2 \times 10^{-13}$ Gy $\mathrm{cm}^{2} / \mathrm{n}$ but the neutron flux values $>1,0 \times 10^{9} \mathrm{n} / \mathrm{cm}^{2}$ s. Filter serves to reduce the thermal neutron flux and fast neutron flux, so that only passed the epithermal neutron flux. With good criteria filter material is a material that has a high absorption cross section. Serves to shield gamma gamma in order to absorb the gamma rays coming out of the aperture can be minimized. Criteria for a good gamma shield material is having a density, atomic number and coefficient ettenuasi great. Materials that effectively absorb gamma are $\mathrm{Pb}$-nat and ${ }^{209} \mathrm{Bi}$.

\section{Object design in vivo testing BNCT}

Simulation geometry test sample with laboratory rats objects already in the injection of cancer cells that are used. Mouse model is the reference for the design of in vivo test with 
specified MCNP [6] are shown in Fig.1. Modeling is done with rats awake approach ellipsoid. Tumor samples used are part of the liver of mice that modeled the ellipsoid shape as well. The geometry modeling agency elipsoida mice with a mouse model of the most simple compared NCTplan models or models Xplan as on research [7].

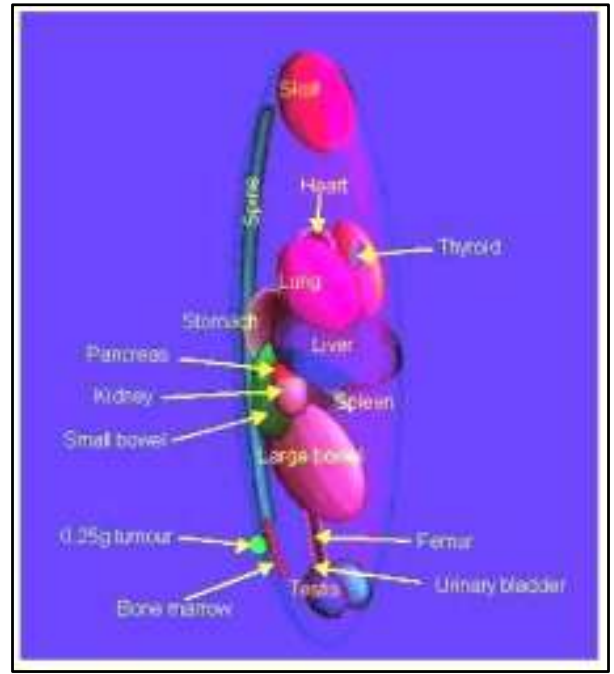

Fig.1 Visualization of the model mice [6]

The output generated from MCNP calculations include gamma dose rate, neutron dose rate, neutron flow and neutron flux values that have been written on the tally code MCNPX. The values resulting from the calculation MCNPX will be used in the calculation of the dose. Boron dose is the dose calculation, dose gamma interacts with matter, dose and dose proton neutron scattering.

\section{RESULTS}

\section{The Optimization of Collimator in Radial}

\section{Piercing Beamport}

The parts that are used in the optimization of collimator including collimator wall (reflector), moderator, filter and shield gamma. In this study collimator wall using Ni-nat $156 \mathrm{~cm}$ long and has a thickness of 1,75 cm Data is derived from previous studies that produce epithermal neutron flux values are quite high and a diameter of $3 \mathrm{~cm}$ aperture.

a. Moderation

Parameters into consideration to choose a good moderator is epithermal high flux value, the value of fast neutron component $\dot{\mathrm{D}}_{\mathrm{f}} / \Phi_{\text {epi }}$ were small $\left(<2 \times 10^{-13}\right)$ and epithermal neutron flux ratio with fast neutron flux $\left(\Phi_{\text {epi }} / \Phi_{\text {fast }}\right)$ tall one.

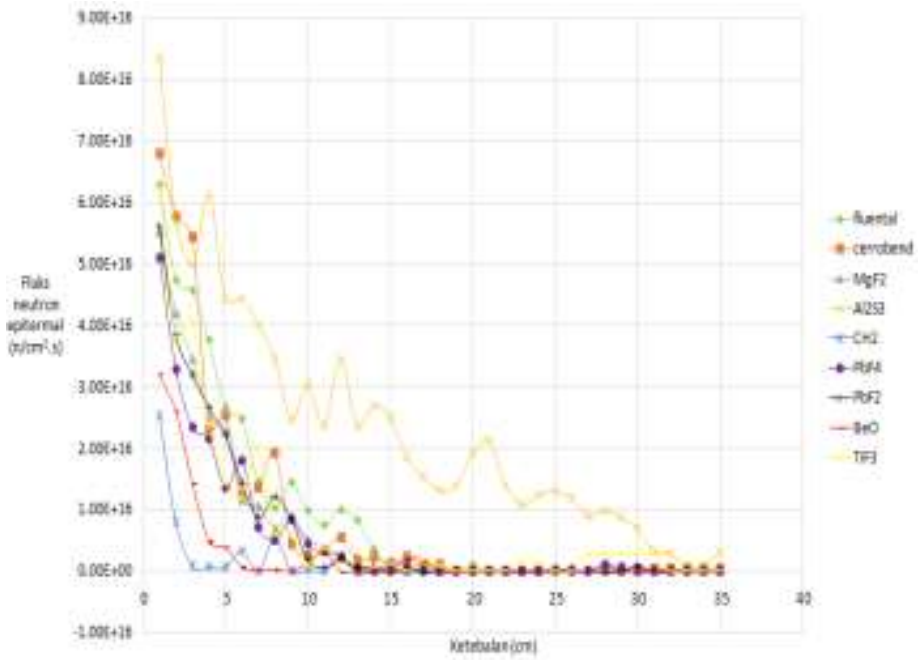

Fig.2 Epithermal neutron flux values versus material thickness moderator

Fig.2 shows the epithermal neutron flux values for some of the material versus the thickness of the material. Seen from the graph that the material is thinking about the high value of the thickness of the material $\mathrm{Al}_{2} \mathrm{~S}_{3}$ young to have increased thickness epithermal flux values are still high compared with other moderator material. 


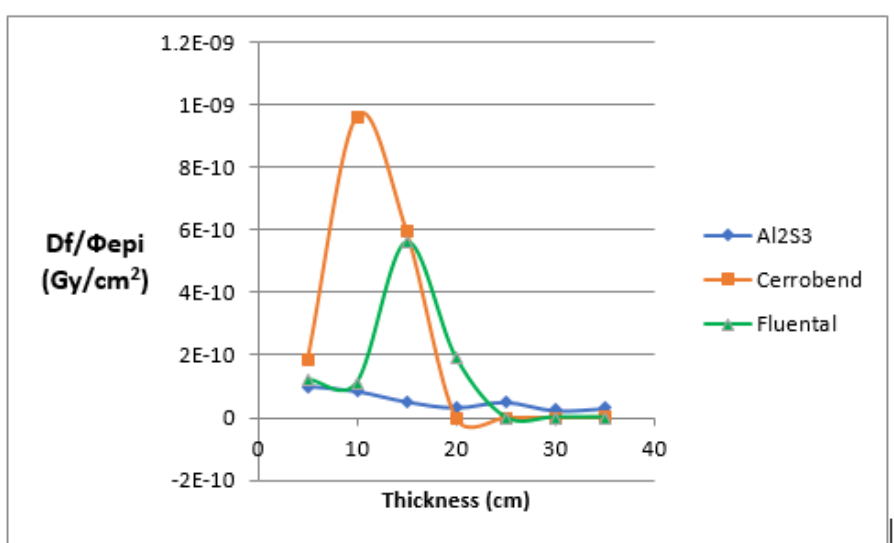

Fig. 3 Value $D_{f} / \Phi_{\text {epi }}$ vs thickness of the material best moderator

Fig. 3 shows the value $\mathrm{D}_{\mathrm{f}} / \Phi_{\text {epi }}$ to three different materials versus thickness, the third material is $\mathrm{Al}_{2} \mathrm{~S}_{3}$, Fluental and Cerrobend. The third election is because the material has a third epithermal neutron flux values higher than in other materials shown in Fig.3 The elements that make up $\mathrm{Al}_{2} \mathrm{~S}_{3}$ have a small mass number. Fluental material is a material consisting of ( $\mathrm{Al}$ $30 \%+69 \%+\mathrm{LiF} \mathrm{AlF}_{3} 1 \%$ ), and Cerrobend consisting of (Bi 50\%, 31,8\% $\mathrm{Pb}$ and $\mathrm{Sn}$ 18.2\%). Criteria for selection of the best material is when the value $\mathrm{D}_{\mathrm{f}} / \Phi_{\text {epi }}$ decreases with the value of $\mathrm{D}_{\mathrm{f}} / \Phi_{\text {epi }}$. From these criteria only $\mathrm{Al}_{2} \mathrm{~S}_{3}$ that still have value $\mathrm{D}_{\mathrm{f}} / \Phi_{\text {epi }}$ high for large thicknesses of data while the other material values $\mathrm{D}_{\mathrm{f}} / \Phi_{\text {epi }}$ already zero. $\mathrm{Al}_{2} \mathrm{~S}_{3}$ better used to be a moderator than the other two materials.

\section{b. Filtering}

Filtering is done to reduce the thermal neutron flux and fast neutron flux, so that only passed the epithermal neutron flux. Materials were chosen as the filter is a material that has the look of the reaction $(n, 2 n)$ high. The type of filter used is a band pass filter, is intended to effectively skip the epithermal neutron, including $\mathrm{Ni}, \mathrm{Fe}$ and $\mathrm{Al}_{2} \mathrm{O}_{3}$. To use $\mathrm{Al}_{2} \mathrm{O}_{3}$ intended to determine effectiveness fast neutron flux filter.

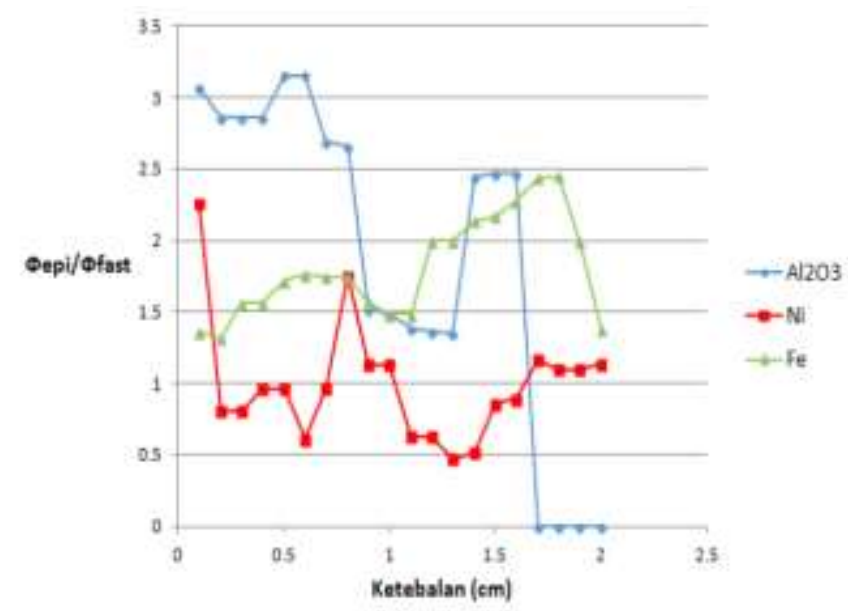

Fig.4 Value $\Phi_{\text {epi }} / \Phi_{\text {fast }}$ Vs the thickness of the filter material

Fig.4 shows that an effective material to produce a ratio $\Phi_{\text {epi }} / \Phi_{\text {fast }}$ high is material $\mathrm{Al}_{2} \mathrm{O}_{3}$ and ${ }^{56} \mathrm{Fe} . \mathrm{Al}_{2} \mathrm{O}_{3}$ for a low thickness mampunyai value $\Phi_{\text {epi }} / \Phi_{\text {fast }}$ highest while for ${ }^{56} \mathrm{Fe}$ much lower. But for a much larger thickness value $\Phi_{\text {epi }} / \Phi_{\text {fast }}$ much higher for ${ }^{56} \mathrm{Fe}$ material compared with $\mathrm{Al}_{2} \mathrm{O}_{3}$. This is because the material ${ }^{56} \mathrm{Fe}$ has the ability to filter out the most excellent fast neutrons but because it is easily corrosive so it can not be used for a relatively long time so that the use of $\mathrm{Al}_{2} \mathrm{O}_{3}$ with a small thickness is more effective than the use of ${ }^{56} \mathrm{Fe}$ for high thickness. In part this filter material that effectively is a $\mathrm{Al}_{2} \mathrm{O}_{3}$ with a thickness of $0,5 \mathrm{~cm}$.

c. Gamma shielding

Gamma shield serves to absorb the gamma rays that magma that came out of the aperture can be minimized. Two effective material that absorbs gamma-nat is $\mathrm{Pb}$ and 
${ }^{209} \mathrm{Bi}$. Two effective material that absorbs gamma-nat is $\mathrm{Pb}$ and ${ }^{209} \mathrm{Bi}$. The following are shown in Table 1.

Table.1 Value $\Phi_{\text {epi }}$ and $\mathrm{D}_{\gamma} / \Phi_{\text {epi }}$ vs gamma shield material thickness of the end of the collimator

\begin{tabular}{ccc}
\hline $\begin{array}{c}\text { Thickness pb } \\
\text { and bi }(\mathrm{cm})\end{array}$ & $\begin{array}{c}\Phi_{\boldsymbol{e p i}} \times \\
\mathbf{1 0}^{\mathbf{9}}\left(\mathrm{n} / \mathrm{cm}^{2}\right. \\
\mathrm{s})\end{array}$ & $\begin{array}{c}\dot{\mathbf{D}}_{\boldsymbol{\Gamma}} / \Phi_{\mathbf{e p i}} \times \\
\mathbf{1 0}^{-\mathbf{1 3}}(\mathrm{gy} \\
\left.\mathrm{cm}^{2} / \mathrm{n}\right)\end{array}$ \\
\hline 1 & 4.4 & 286 \\
\hline 2 & 7.5 & 99 \\
\hline 3 & 6.9 & 82 \\
\hline 4 & $\mathbf{5 . 4}$ & $\mathbf{5 0}$ \\
\hline 5 & 2.2 & 60 \\
\hline 6 & 2.1 & 81 \\
\hline 7 & 2.1 & 48 \\
\hline 8 & 2.1 & 44 \\
\hline 9 & 2.1 & 21 \\
\hline 10 & 0 & 0 \\
\hline
\end{tabular}

Election of the end of the gamma shield collimators with $\mathrm{Pb}$ and $\mathrm{Bi}$ constituent material thickness of $4 \mathrm{~cm}$ due consideration high value Фepi and the value of $\mathrm{D}_{\gamma} / \Phi_{\text {epi }}$ lowest. This value is still higher than the standard IAEA value doses of gamma must be lower than $2 \times 10^{-13}$ so that the necessary efforts to continue to lower it by adding a shield gamma part of the base of the collimator to the type of the same material and varying the thickness of the material the.

Table. 2 shows the value $\mathrm{D}_{\gamma} / \Phi_{\text {epi }}$ much smaller compared to the addition of gamma shield at the end of the collimator only. Result of adding gamma shield at the end of the collimator only have value $\mathrm{D}_{\gamma} / \Phi_{\text {epi }}$ approximately $50 \times 10^{-13} \mathrm{~Gy} \mathrm{~cm}^{2} / \mathrm{n}$ but after adding a gamma shield at the base of the collimator value $\mathrm{D}_{\gamma} / \Phi_{\text {epi }}$ decreased to $3,1 \times 10^{-}$ ${ }^{13} \mathrm{~Gy} \mathrm{~cm}^{2} / \mathrm{n}$.
Table.2 Value $\dot{\mathrm{D}}_{\gamma} / \Phi_{\text {epi }}$ vs Bi gamma shield material thickness at the base of the collimator

\begin{tabular}{cc}
\hline $\begin{array}{c}\text { Thickness } \\
(\mathrm{cm})\end{array}$ & $\begin{array}{c}\dot{\mathbf{D}}_{\boldsymbol{\gamma}} / \boldsymbol{\Phi}_{\mathbf{e p i}} \times \mathbf{1 0}^{-\mathbf{1 3}} \\
(\mathrm{Gy} \mathrm{cm} / \mathrm{n})\end{array}$ \\
\hline 1 & 17.5 \\
\hline 1.1 & 180 \\
\hline 1.2 & 110 \\
\hline 1.3 & 4.4 \\
\hline 1.4 & 3.8 \\
\hline $\mathbf{1 . 5}$ & $\mathbf{3 . 1}$ \\
\hline 1.6 & 17.8 \\
\hline 1.7 & 20 \\
\hline 1.8 & 6.7 \\
\hline 1.9 & 6.7 \\
\hline 2.0 & 6.4 \\
\hline
\end{tabular}

d.The optimization result

Table.3 Results Collimator System Optimization

\begin{tabular}{|c|c|c|c|c|c|}
\hline Criteria & $\begin{array}{c}\mathrm{n} / \mathrm{cm}^{2} \\
\mathrm{~s})\end{array}$ & $\mathrm{J} / \Phi_{\text {tot }}$ & $\begin{array}{l}\Phi_{\text {term }} \\
/ \Phi_{\text {epi }}\end{array}$ & $\begin{array}{c}\dot{\mathbf{D}}_{\mathbf{f}} \\
/ \Phi_{\text {epi }} \\
\\
\begin{array}{c}\mathrm{Gy} \\
\left.\mathrm{cm}^{2} / \mathrm{n}\right)\end{array}\end{array}$ & $\begin{array}{l}\dot{\mathbf{D}}_{\gamma} \\
/ \Phi_{\text {epi }} \\
\\
\left.\mathrm{cm}^{2} / \mathrm{n}\right)\end{array}$ \\
\hline IAEA & $\begin{array}{l}>1.0 \\
\times 10^{9}\end{array}$ & $>0,7$ & $<0,5$ & $\begin{array}{l}<2 \\
\times 10^{-13}\end{array}$ & $\begin{array}{l}<2 \\
\times 10^{-13}\end{array}$ \\
\hline Design & $\begin{array}{l}2,92 \\
\times 10^{9}\end{array}$ & 1.16 & 0,2 & $\begin{array}{l}1,41 \\
\times 10^{-13}\end{array}$ & $\begin{array}{l}3,15 \\
\times 10^{-13}\end{array}$ \\
\hline
\end{tabular}

Table.3 shows the optimum results from this study with a design specification is reflector collimator system using Ni-nat 156 $\mathrm{cm}$ and a thickness of $1.75 \mathrm{~cm}$, a moderator using the material at a thickness of $29 \mathrm{~cm}$ $\mathrm{Al}_{2} \mathrm{~S}_{3}$, filter using $\mathrm{Al}_{2} \mathrm{O}_{3}$ material with a thickness of $0,5 \mathrm{~cm}$ and a gamma shield the tip collimator using $\mathrm{Pb}$ and $\mathrm{Bi}$ material with a thickness of $4 \mathrm{~cm}$ and gamma shield collimators the base using a $1,5 \mathrm{~cm}$ thick $\mathrm{Bi}$ material as shown in Fig.5. 


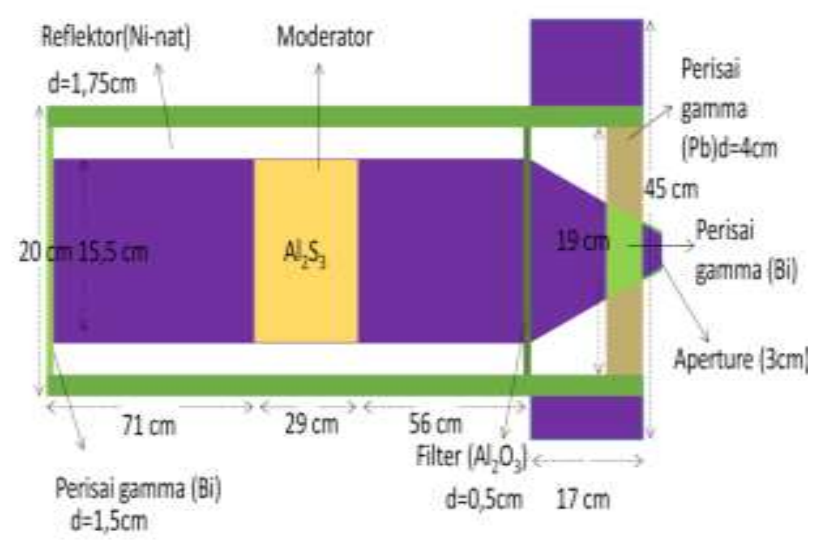

Fig.5 The System Design Collimators

\section{IV.DISCUSSION}

This research was conducted referring to the results of previous research conducted by performing design improvements and adding parameters for testing on test animals [8]. It has been improved in this study by producing the optimal collimator design as in figure 5 by in vivo test taking into account the value of the components shown in Table 3.

BNCT therapy uses a boron compound, in which the boron compound has a very low toxicity level. Boron is a toxic compound if its use does not follow the prescribed dose. The optimum concentration of ${ }^{10} \mathrm{~B}$ in cancer cells is $20 \mu \mathrm{g} \mathrm{B} / \mathrm{g}$ [9], which is the optimum concentration of ${ }^{10} \mathrm{~B}$ which is non-toxic. If the concentration exceeds that dose then ${ }^{10} \mathrm{~B}$ will be toxic, but if it is less then the absorption of cancer cells that have been corrected become less optimum, so the absorption of neutrons is less than the maximum.

This research still has a drawback that is still to be done by choosing the compiler of collimator having high economical value and based on local component. It should be continued by conducting laboratory tests on mice by applying BNCT therapy using Kartini Reactor. Need to make modeling the geometry of mice that are closer and more complex again.

\section{CONCLUSION}

This study concludes that the optimization of collimator designs meets the needs of the IAEA and can be simulated for in vivo test radiation. The results of the optimization of such collimator materials are; epitermal neutron flux $2,92 \times 10^{9} \mathrm{n} / \mathrm{cm}^{2} \mathrm{~s}$, current component $1,16 \mathrm{~cm}^{-1}$, thermal neutron component 0,20 , fast neutron dose component $1,41 \times 10^{-13}$ Gy $\mathrm{cm}^{2} / \mathrm{n}$ and gamma dose components $3,15 \times 10^{-13}$ Gy $\mathrm{cm}^{2} / \mathrm{n}$. Simulation of in vivo in vivo radiation with an optimum Boron-10 concentration of $47 \mu \mathrm{g} / \mathrm{g}$ tumor.

\section{ACKNOWLEDGEMENTS}

This research was supported by grants from consortium of BNCT BATAN Yogyakarta.

\section{REFERENCES}

[1] WHO, Global Status Report on Noncommunicable Diseases, World Health Organization (WHO), Prancis, 2014.

[2] Siegel, R., Ma, J., Zou, Z. and Jemal, A., Cancer Statistics 2014, CA Cancer J Clinical, vol. 64, pp. 9-29. 2014. 
[3] National Cancer Institute, Radiation Therapy and You, USA, 2014.

[4] Savolainen, S., Kortesniem, M., Timonen, M., Reijonen, V., Kuusela, L., Uusi-Simola, J., et, all. Boron neutron capture therapy (BNCT) in Finland Technological and physical prospects after 20 years of experiences, Physica Medica, vol. 29, pp. 233-248, 2013.

[5] Soppera, N., Dupont, E. and Bossant, M., Java-based Nuclear Information Software: Book of Neutron-induced Cross-section, A technical document, Nuclear Energy Agency, Issy-lesMoulineaux. 2012.

[6] Konijnenberg, M.W., Bijster, M., Krenning, E.P. and de Jong, M., A Stylized Computational Model of the Rat for Organ Dosimetry in Support of Preclinical Evaluations of Peptide Receptor radionuclide Therapy with ${ }^{90} \mathrm{Y}$, ${ }^{111} \mathrm{In}$, or ${ }^{177} \mathrm{Lu}$. The Journal of Nuclear Medicine, vol. 45, pp. 1260-1269. 2004.

[7] Liu, Y.H., Lee, P.Y., Lin, Y.C., Chou, F.I., Chen, W.L., Huang, Y.S. and Jiang, S.H. Dose estimation of animal experiments at the THOR BNCT beam by NCTPlan and Xplan, Applied Radiation and Isotopes, vol.88, pp. 125128. 2014.

[8] Wahyuningsih, D. Optimasi Desain Kolimator Untuk Uji In Vivo Boron Capture Therapy (BNCT) pada Beam port Tembus reaktor Kartini Menggunakan Simulasi Monte Carlo Partikel 5 (MCNP5), Tesis, Universitas Gadjah Mada, Yogyakarta, 2014.

[9] Protti, N., The efficacy of Boron Neutron Capture Therapy on Small Animal Models. Disertasi, Dipartimento di Fisica Nucleare e Teorica, Universita Degli Studi di Pavia, Pavia. 2014. 